NBER WORKING PAPER SERIES

TRADE COSTS IN THE FIRST WAVE OF GLOBALIZATION

\author{
David S. Jacks \\ Christopher M. Meissner \\ Dennis Novy \\ Working Paper 12602 \\ http://www.nber.org/papers/w12602
NATIONAL BUREAU OF ECONOMIC RESEARCH
1050 Massachusetts Avenue
Cambridge, MA 02138
October 2006

We appreciate feedback from seminar participants at the Canadian Economics Association, NBER Development of the American Economy Summer Institute, Marie Curie Training Network Conference at Lund, Stockholm School of Economics, TARGET, University of British Columbia, UC Irvine, Warwick, and Yale. Rafael de Hoyos provided helpful early research assistance. Jacks thanks the Social Science and Humanities Research Council of Canada for funding. The authors are responsible for any remaining errors. The views expressed herein are those of the author(s) and do not necessarily reflect the views of the National Bureau of Economic Research.

(C) 2006 by David S. Jacks, Christopher M. Meissner, and Dennis Novy. All rights reserved. Short sections of text, not to exceed two paragraphs, may be quoted without explicit permission provided that full credit, including $(\mathcal{O}$ notice, is given to the source. 
Trade Costs in the First Wave of Globalization

David S. Jacks, Christopher M. Meissner, and Dennis Novy

NBER Working Paper No. 12602

October 2006, revised August 2007

JEL No. F15,N70

\begin{abstract}
$\underline{\text { ABSTRACT }}$ percent is attributable to economic expansion.

David S. Jacks

Department of Economics

Simon Fraser University

8888 University Drive

Burnaby, BC V5A 1S6

Canada

djacks@sfu.ca

Christopher M. Meissner

Faculty of Economics

University of Cambridge

Austin Robinson Building

Sidgwick Avenue

Cambridge CB3 9DD

ENGLAND

and NBER

chris.meissner@econ.cam.ac.uk

Dennis Novy

Department of Economics

University of Warwick

Coventry CV4 7AL

United Kingdom

d.novy@warwick.ac.uk
\end{abstract}

What drives globalization today and in the past? We employ a new micro-founded measure of bilateral trade costs based on a standard model of trade in differentiated goods to address this question. These trade costs gauge the difference between observed bilateral trade and frictionless trade. They comprise tariffs, transportation costs and all other factors that impede international trade but which are inherently difficult to observe. Trade costs fell on average by ten to fifteen percent between 1870 and 1913 . We also use this measure to decompose the growth of global trade over that period and find that roughly 44 percent of the global trade boom can be explained by reductions in trade costs; the remaining 56 


\title{
Trade Costs in the First Wave of Globalization
}

\author{
David S. Jacks, Christopher M. Meissner and Dennis Novy*
}

This version: August 8, 2007

\begin{abstract}
What drives globalization today and in the past? We employ a new micro-founded measure of bilateral trade costs based on a standard model of trade in differentiated goods to address this question. These trade costs gauge the difference between observed bilateral trade and frictionless trade. They comprise tariffs, transportation costs and all other factors that impede international trade but which are inherently difficult to observe. Trade costs fell on average by ten to fifteen percent between 1870 and 1913 . We also use this measure to decompose the growth of global trade over that period and find that roughly 44 percent of the global trade boom can be explained by reductions in trade costs; the remaining 56 percent is attributable to economic expansion.
\end{abstract}

\section{Introduction}

International trade costs are the costs of transaction and transport associated with the exchange of goods across national borders and, thus, impede international economic integration. They may also drive many key findings in the contemporary open-economy macroeconomics literature (Obstfeld and Rogoff, 2000). At the same time, economists know little about the magnitude, evolution, and determinants of these obstacles to international trade (Anderson and van Wincoop, 2004).

Research on the nineteenth century trade boom has tracked certain costs like freight rates and tariffs reasonably well (O'Rourke and Williamson, 1999). But the magnitude and impact of

\footnotetext{
${ }^{*}$ Jacks: Department of Economics, Simon Fraser University, 8888 University Drive, Burnaby, British Columbia V5A 1S6, Canada (email: djacks@sfu.ca); Meissner: University of California, Davis, Department of Economics, One Shields Avenue, Davis, CA 95616 (email: chris.meissner@econ.cam.ac.uk) and NBER; Novy: Department of Economics, University of Warwick, Coventry CV4 7AL, England (email: d.novy@warwick.ac.uk). We appreciate feedback from seminar participants at the Canadian Economics Association, NBER Development of the American Economy Summer Institute, Marie Curie Training Network Conference at Lund, Stockholm School of Economics, TARGET, University of British Columbia, UC Irvine, Warwick, and Yale. Rafael de Hoyos provided helpful early research assistance. Jacks thanks the Social Science and Humanities Research Council of Canada for funding. The authors are responsible for any remaining errors.
} 
a host of other important impediments to trade that are inherently difficult to measure like nontariff barriers, information costs, distribution channels, market micro-structures, legal frictions, and the costs of uncertainty remain unexplored. As a step towards a better understanding of these costs, our strategy is to move beyond the study of individual commodities and particular trade cost elements to a more general approach derived from sound economic theory.

We present a new comprehensive measure of international trade costs. We study trade costs that are broadly defined and encompass not only shipping costs and tariffs but also many other informational, institutional, and non-tariff barriers to trade. Our focus is on the first wave of globalization from 1870 to 1913, a period that experienced many changes in trade costs and substantial growth in trade.

Our measure is derived from a micro founded gravity model of trade that is fully consistent with the state-of-the-art gravity equation literature (e.g., Anderson and van Wincoop, 2003). The framework is a multiple-country general equilibrium model of trade in differentiated goods based on Novy (2007). We include bilateral trade costs and emphasize that to be consistent with the theory these must be measured against trade costs with all other trade partners. Anderson and van Wincoop (2003) call this multilateral resistance, and our measure captures this.

The innovation here is to model and control for multilateral resistance in a tractable, yet previously un-noticed way. This makes it possible to back out the bilateral trade costs from the model's gravity equation of international trade. It also obviates the estimation of arbitrary specifications of the trade cost function which is a typical feature of the current gravity literature. Instead, we compute trade costs directly on the basis of bilateral trade, total trade and output data.

The average level of trade costs between the US, UK, France and their trading partners fell by ten to fifteen percent in the forty years before World War I. Trade costs declined at a rate of about 0.3 percent per year for the average country pair. The annual fall in trade costs was therefore not as large as the roughly two percent annual decline in freight indices between 1870 and 1913 noted by Harley (1988) and Shah Mohammed and Williamson (2004). The difference can easily be reconciled. Transportation costs are only one input into trade costs, as 
emphasized by Anderson and van Wincoop (2004). The factors contributing to declines in trade costs include ocean shipping freight rates, the rise of the classical gold standard and improved communication technology. On the other hand, international trade costs did not fall as quickly as they might have because of tariffs (measured as tariff revenue relative to total imports) that rose on average by 50 percent between 1870 and 1913, new non-tariff barriers, and ostensibly faster domestic integration. ${ }^{1}$

This allows for an interpretation of the late nineteenth century in which overall declines in aggregate trade costs were much smaller than the observed decline in maritime freight rates. Nevertheless, this is still compatible with a 'first wave of globalization' since small changes in trade costs can be sufficient to generate large increases in trade flows as argued by Obstfeld and Rogoff (2000). And in fact, there is no question that these changes are most likely the principal drivers of the rise in the share of output devoted to international trade. We argue and demonstrate that one does not need to appeal to large changes in trade costs to see the doubling in the export to GDP ratio reported by O'Rourke and Findlay (2003).

After examining the levels and trends in trade costs, we turn to the determinants of trade costs. This exercise underscores that our trade cost measure is reliable. In particular, our evidence suggests that standard variables like geographic proximity, trade policy, transportation costs, adherence to the gold standard, and membership in the British Empire matter in sensible ways for explaining trade costs.

Turning to the question of what drives globalization episodes, we use the micro-founded gravity equation to attribute the growth in global trade to two fundamental driving forces - the growth in productive capacity and the decline in trade costs. In line with the post-World War II experience (see Baier and Bergstrand, 2001 and Whalley and Xin, 2007), we find that roughly 56 percent of the global trade boom prior to World War I was due to the growth in productive capacity and 44 percent was due to the decline in trade costs. We unmask a substantial degree

\footnotetext{
${ }^{1}$ See Williamson (2006) on the global rise in tariffs measured as tariff revenue divided by import values. His world average rises from 12 percent in 1865 to 17.5 percent in 1900. See Saul (1967) for a discussion of non-tariff barriers. See Jacks (2005) on domestic integration based on wheat price data. He shows much faster withincountry integration than cross-border integration. A fall in the cost of domestic trade (all else equal) makes international trade relatively more costly.
} 
of heterogeneity between core and periphery performance. Economic expansion contributes the lion's share of trade growth for core countries while trade cost declines dominate for the periphery.

\section{Historical Perspectives on Trade Costs}

Economic historians generally concede that the fifty years before World War I comprise a period of globalization akin to our own in many respects. The world economy witnessed sustained increases in international commodity, capital, and labor flows (O'Rourke and Williamson, 1999 and Obstfeld and Taylor, 2004). Historical accounts, as well as popular conceptions of trade in the years from 1870 to 1913, have generally stressed the singular role played by developments in transportation and communication technologies in conquering time and space. The extension of the railroad and telegraph networks take pride of place in promoting economic integration domestically and in helping move goods to ports. In this view the increased use of steam ships and persistent improvements in shipping technology play a similar role with respect to international markets (see Frieden, 2006, p. 19 and James, 2001, pp. 10-13).

In the most influential contribution to this literature, O'Rourke and Williamson accordingly write that the "impressive increase in commodity market integration in the Atlantic economy [of] the late nineteenth century" was a consequence of "sharply declining transport costs" (1999, p. 33). Their metric for integration is the narrowing of price gaps for key commodities such as wheat and iron. The data on this commodity price convergence throughout the nineteenth century is extensive and well-documented (O'Rourke and Williamson, 1994 and Jacks, 2005). However, O'Rourke and Williamson (1999) are quick to point out that a host of other factors could also be responsible for the dramatic boom in global trade during the period, chief among them being increases in GDP and import demand.

What about other costs of trade besides transport? Recent research suggests a strong role for developments outside the communication and transportation sectors. Jacks (2006) offers evidence from a number of North Atlantic grain markets between 1800 and 1913 that freight costs can only explain a relatively modest fraction of trade costs in those markets. Jacks 
concludes that trade costs were also powerfully influenced by the choice of monetary regime and commercial policy as well as the diplomatic environment in which trade took place. Even so, a substantial portion of trade costs are left unexplained by these observables.

A different strand in the literature has examined integration based on the gravity approach to international trade. Estevadeordal, Frantz and Taylor (2003), Flandreau and Maurel (2001), and López-Córdova and Meissner (2003) find that distance, tariffs, monetary regime coordination as well as cultural and political factors played a very important role in explaining global trade patterns.

And what of the view from the nineteenth century itself? The perceived factors were manifold but could be boiled down to technological, informational, and institutional ones. Such views are summarized in an 1897 study of trade costs in the British colonies conducted and published at the request of Joseph Chamberlain (Trade of the British Empire and Foreign Competition, 1897). The report surveyed colonial governors as to the reasons why non-Empire producers were gaining market share in the British Empire.

From their comments, it is obvious that determining total trade costs is more complex than adding together an ad valorem tariff value and unit shipping costs. Shipping costs were difficult to calculate directly as they varied by good, season, and with local economic conditions. The governor of the colony of Victoria in Australia hesitated to give an average of the freight costs from Europe due to such fluctuations. The diffusion of the steamship was no simple matter either as it favored certain classes of goods while sailing ships, still in heavy use on many longer routes as late as 1894, favored others. There were also government subsidies on several, but not all, key liners traveling between East Asia and Europe. All of this suggests that any single freight index based on only a few commodities and routes is bound to be problematic if used as a summary measure of shipping costs.

Other governors also noted how differential marketing techniques, proximity, information about local tastes and needs, credit practices, the relative quality and appearance of goods, exchange rate stability, and even the precise weights and measures used in the marketing process helped determine trade flows. Moreover, Saul (1967) discusses at length how non-tariff barriers 
were impeding trade. Discriminatory railway tariffs, health and safety regulations, along with conditional clauses to trade treaties and lengthy legal delays in challenging them featured in the late nineteenth century trading system.

What all of this evidence suggests is that our knowledge of the drivers and level of international integration in the nineteenth century has a gap. Moving beyond the study of individual commodities and particular trade cost elements to a more general attack on the issue may be beneficial in this regard. We now show how to measure trade costs this way.

\section{International Trade in General Equilibrium with Trade Costs}

Recent theoretical advances in the trade literature have revived interest in trade costs as a determinant of bilateral trade. In their state-of-the-art contribution, Anderson and van Wincoop (2003) provide a now widely used method to estimate the elasticity of trade with respect to specific bilateral trade barriers. Moreover, they show how to avoid an omitted variables bias in such an estimation. They demonstrate that the volume of trade between two countries is not only determined by their bilateral trade barrier but also by their trade barriers with all other trading partners. These 'multilateral' barriers are appropriately weighted averages of all bilateral barriers. Intuitively, what matters for the volume of trade between two particular countries is how their bilateral barrier compares to other bilateral barriers.

Novy (2007) shows that multilateral trade barriers can simply be related to a country's total exports. The intuition is that the more a country exports, the lower must be its trade barriers with other countries. Given this way of controlling for time-varying multilateral resistance, the model goes on to derive an analytical solution for micro-founded bilateral trade costs that depends on observable variables such as trade and output data. It therefore becomes possible to compute bilateral trade costs over time. This is the strategy that we pursue in this paper.

It is important to stress that the model by Novy (2007) is based on the same multiplecountry general equilibrium framework as the model by Anderson and van Wincoop (2003). In particular, goods are differentiated by country and consumers love variety, so we use a standard CES Dixit-Stiglitz consumption index. Trade between countries is costly, as captured by iceberg 
trade costs.

The innovation of the theoretical model is twofold. First, as already mentioned, the model provides a convenient way of controlling for multilateral resistance so that it becomes possible to solve for bilateral trade costs. This simplification implies that we do not need to impose any particular structure on trade costs either as to the set of determinants or their underlying functional form. ${ }^{2}$ Second, the model relaxes the assumption made by Anderson and van Wincoop (2003), and nearly all of the gravity literature, that all goods are tradable. When computing trade costs, we explicitly allow for the fact that some goods are nontradable. Below we test the sensitivity of all of our results to this modification and show that our central findings are robust.

Since many trade cost components are not directly observable, the need for a micro-founded trade model to infer total trade costs is evident. Our trade cost measure is comprehensive because it captures a wide range of trade frictions. We do not restrict our interpretation of trade costs to well-known trade barriers such as tariffs and transportation costs. Following Anderson and van Wincoop (2003, 2004) and Eaton and Kortum (2002), we acknowledge that many sizeable trade cost components such as language barriers, communication costs and nontariff barriers are not directly observable or measurable in price differentials alone.

Finally, it should be emphasized that we consider aggregate trade and thus a very large range of goods. The price gap methodology is simplicity itself but is restricted to only a few goods due to data limitations and rests on an implicit arbitrage equation and the absence of price discrimination (see Section 4 in Anderson and van Wincoop, 2004). We base our results on a proven trade model - the gravity model. As in any other gravity model, we have to impose assumptions on the elasticity of substitution and the aggregate tradability of the economy to generate an estimate of bilateral trade costs. But as we show in the appendix, neither of these two assumptions are too strong for our empirical conclusions. Overall, we view our methodology as complementary to measures of price gaps. We therefore think that both approaches have

\footnotetext{
${ }^{2}$ The gravity equations by Baier and Bergstrand (2001) and Anderson and van Wincoop (2003) include unobservable and highly nonlinear price indices. Baier and Bergstrand (2001) only consider transportation costs and tariffs, whereas Anderson and van Wincoop (2003) assume that trade costs are a function of distance and a border barrier.
} 
advantages and shortcomings and, while focusing on different aspects, each can provide valuable insights into the integration of world markets.

\subsection{A Gravity Equation with Trade Costs}

This section provides a brief outline of the Novy (2007) model. The details of the model are given in the technical appendix for reference. The model is general equilibrium and comprises multiple countries that can vary in size. In each country, monopolistically competitive firms produce differentiated goods. Optimizing individuals receive utility from consuming a large variety of both domestic and foreign goods. When goods are shipped from country $j$ to country $k$, exogenous iceberg trade $\operatorname{costs} \tau_{j, k}$ are incurred, meaning that for each unit the fraction $\tau_{j, k}$ melts away during the trading process as if an iceberg were shipped across the ocean. Modeling trade costs in this way is well established and customary in the literature; for example see Samuelson (1954), Krugman (1980) and Anderson and van Wincoop (2003) whose representation of trade costs is equivalent to using iceberg trade costs.

We emphasize that trade $\operatorname{costs} \tau_{j, k}$ actually capture what makes international trade more costly over and above intranational trade. For more details on this point see Novy (2007) and Anderson and van Wincoop (2004, p. 716). ${ }^{3}$ We also follow the literature by making the standard assumption of trade cost symmetry $\left(\tau_{j, k}=\tau_{k, j}\right)$, and without loss of generality we normalize intranational trade costs to zero (see for example Baier and Bergstrand, 2001).

The equilibrium solution of the model gives rise to the following micro-founded gravity equation

$$
E X P_{j, k} E X P_{k, j}=s_{j}\left(G D P_{j}-E X P_{j}\right) s_{k}\left(G D P_{k}-E X P_{k}\right)\left(1-\tau_{j, k}\right)^{2 \rho-2}
$$

where $G D P_{j}$ is real output of country $j, E X P_{j, k}$ are real exports from $j$ to $k$ and $E X P_{j} \equiv$ $\sum_{k \neq j} E X P_{j, k}$ are total real exports from $j$. The elasticity of substitution is given by $\rho$ and $s_{j}$

\footnotetext{
${ }^{3}$ This point can be seen in the example of grain shipments from the US to the UK after 1850. Much of the decrease in the price gap between England and the US came through a narrowing of price gaps between the Midwest and the East coast. Better and cheaper transportation networks improved the links between the Midwest and the Atlantic ports. In this case we might see commodity price convergence between Chicago and Liverpool but little change in trade shares. Federico and Persson (2007) examine this issue in detail.

${ }^{4}$ Even if the two bilateral trade barriers are asymmetric, their geometric average corresponds precisely to the trade costs implied by the symmetry assumption. Our trade costs can therefore be interpreted as an average of the barriers in both directions. See Anderson and van Wincoop (2003, p. 175) for details.
} 
is the fraction of the entire range of goods produced in country $j$ that are tradable.

Empirically we distinguish between traded and tradable. Goods may be tradable but traded in only very small quantities or not at all due to prohibitive trade costs. For instance, beef from Argentina could have been exported to Europe at great cost prior to modern refrigeration technology, so we would classify this product as tradable throughout the period but not very heavily traded. Some portion of the range of goods produced, however, is inherently nontradable such as government defense services and so forth.

Our gravity equation is not a function of a simple GDP term. As in any gravity equation, bilateral trade flows are an increasing function of productive capacity and a decreasing function of trade frictions. The innovation of micro-founded gravity equation (1) is to show that the total export terms encompass multilateral trade barriers in a convenient and practical way. In particular, the size variables $G D P-E X P$ are theoretically appropriate controls for multilateral resistance (see the technical appendix for a formal derivation). For example, suppose that exports of country $j$ with all other countries besides $k$ increase so that $E X P_{j}$ increases. Hold all else equal on the right hand side of equation (1). Then $E X P_{j, k} E X P_{k, j}$ must go down. The intuition is as follows. For total exports $E X P_{j}$ to increase, country $j$ 's trade costs with other countries must have decreased, for instance $\tau_{j, l}$ with $l \neq k$. Trade with country $k$ has therefore become relatively more costly, leading to the decrease in $E X P_{j, k} E X P_{k, j}$. Equation (1) thus captures the point forcefully made by Anderson and van Wincoop (2003) that trade flows are not only determined by bilateral trade $\operatorname{costs} \tau_{j, k}$ but also by multilateral trade barriers.

\subsection{A Micro-Founded Measure of Trade Costs}

Since equation (1) relates multilateral resistance to total export terms, it becomes possible to rearrange equation (1) so as to directly solve for trade costs $\tau_{j, k}$ as a function of observable variables. Rearrange (1) to obtain

$$
\tau_{j, k}=1-\left(\frac{E X P_{j, k} E X P_{k, j}}{s_{j}\left(G D P_{j}-E X P_{j}\right) s_{k}\left(G D P_{k}-E X P_{k}\right)}\right)^{\frac{1}{2 \rho-2}}
$$

This is our key equation. Trade costs are not estimated. They are simply calculated directly as a function of the trade and GDP data. Equation (2) shows intuitively that if trade flows 
between $j$ and $k$ have increased but productive capacity in the two countries has remained constant, then trade costs must have come down to facilitate the increase in trade. Conversely, if trade flows between $j$ and $k$ have remained constant but productive capacity has increased, then trade costs must have gone up because the increase in output has not fed through to trade.

Note that productivity changes do not affect $\tau_{j, k}$. Consistent with the overwhelming majority of models in the New Open Economy Macroeconomics literature, the production function is linear in productivity (see the technical appendix and Obstfeld and Rogoff, 1995). An increase in the productivity of country $j$ will therefore feature multiplicatively in bilateral exports, in total exports, and in GDP and will therefore cancel out in equation (2). The intuition is that price changes arising from productivity changes affect all consumers both domestic and foreign. Trade costs measure the relative cost of international versus domestic trade.

We consider aggregate trade flows between $j$ and $k$ such that $\tau_{j, k}$ is a measure of aggregate trade costs. Trade in particular goods like wheat or coal is not our focus. Also, our trade costs are country-pair specific and it is easy to compute the change of these trade costs over time. As shown in the technical appendix, trade cost measure (2) is also valid in the more general case when countries run trade deficits or surpluses.

\section{Empirical Trade Costs}

\subsection{Data and Methods}

In this section, we provide an overview of trends in trade costs from 1870 to 1913. To compute trade costs, we make use of the expression given in (2). All that is needed is bilateral trade data, and data on total exports and GDP. We have such annual data for 18 countries. ${ }^{5}$ This sample accounts for over 60 percent of world GDP and trade in 1913. The GDP data was taken from Maddison (1995) while the trade data was taken from the Tableau Général du Commerce de la France avec ses Colonies et les Puissances Etrangères (various years), the Statistical Abstract of the United Kingdom (various years) and the Statistical Abstract of the United States (various

\footnotetext{
${ }^{5}$ Our sample includes: Australia, Belgium, Brazil, Canada, Denmark, Dutch East Indies, France, Germany, Italy, Japan, Netherlands, New Zealand, Norway, Portugal, Spain, Sweden, the United Kingdom, and the United States.
} 
years). We consider all French, UK, and US destined or originated bilateral trade for which there is also a full set of GDP data (15 countries plus France, the UK, and the US). Thus, the full panel of trade costs is balanced and evenly weighted between French, UK, and US trade with 2,112 unique dyadic observations in total. In the regressions below, fifteen observations are lost for countries with no railways (Japan before 1872 and New Zealand before 1873), but this is not expected to impart any systematic bias.

Two parameter assumptions are necessary to compute trade costs. We direct the reader to Appendix B which demonstrates that the overall qualitative results are not too sensitive to these assumptions. For the reported results, the fraction of tradable goods produced, $s$, was set to 0.8 while the elasticity of substitution, $\rho$, was set to eleven. ${ }^{6}$

\subsection{Results}

The resulting trade cost series can be seen in Figures 3 and 4 . Figure 3 presents the simple average of trade cost levels for the three countries. Figure 4 presents the indexed value of these trade costs over time $(1870=100)$. A few important elements are clearly documented. First, as seen in Figure 3, France and the United Kingdom enjoyed substantially lower trade costs than the United States for the entire period, perhaps reflecting not only the maturity of their trading relationships but also their greater proximity to many of the world's leading markets. Second, the initial level of trade costs seems to condition their subsequent evolution: the United States experienced a much more dramatic decline in trade costs over time, 16 percent ( 7.7 percentage points) versus France's 13 percent decline and the UK's 10 percent (5.5 and 3.7 percentage points, respectively). Finally from Figure 4, it seems that most of the decline in trade costs, especially for France and the United Kingdom, was concentrated between 1870 and 1880. This was, of course, a time of simultaneously declining freight rates and tariffs as well as increasing

\footnotetext{
${ }^{6}$ When the elasticity of substitution is set equal to eleven, this corresponds to a ten percent markup over marginal cost. Irwin (2003) shows rough evidence of a 9.8 percent markup in American steel and pig iron products in the late nineteenth century. Typical estimates in the contemporary literature, based on recent data comprising goods that are more differentiated and therefore less substitutable, are around seven or eight as noted in Anderson and van Wincooop (2004). Evenett and Keller (2002) suggest that the share of output in recent years that is tradable is in the range of 0.3 to 0.8. Stockman and Tesar (1995) argue that the share of tradable output would be in the range of 0.65 and 0.82 . Moreover, it is decreasing in the size of the service and public sector which are typically nontradable. Both sectors were much less significant in terms of total output in our period.
} 
adherence to the gold standard.

\section{The Determinants of Trade Costs}

Researchers have focused on transportation, communication costs, tariffs, national borders, and currency unions as determinants of trade costs. Little consensus exists on the functional form that best describes trade costs. As our baseline, and following the bulk of previous work so as to provide comparable results, we consider a log-linear specification of iceberg trade costs of the following form:

$$
\tau_{j k t}=D i s t_{j k}^{\delta} e^{\beta_{0}+\beta_{1} X_{j k t}+\eta_{j k t}}
$$

where $\beta_{1}$ is a vector of coefficients, Dist ${ }_{j k}$ is the great-circle distance between two countries' capitals, $\delta$ is the elasticity of iceberg trade costs with respect to distance, and $\eta_{j k t}$ is a composite error term. This implies the following estimating equation:

$$
\ln \left(\tau_{j k t}\right)=\beta_{0}+\delta \ln \left(D_{i s t_{j k}}\right)+\beta_{1} X_{j k t}+d_{t}+v_{j k}+\varepsilon_{j k t}
$$

where we allow for the composite error term to consist of a country-pair specific component $v_{j k}$ (i.e., a fixed effect or a random effect) and a country-pair white noise error term $\varepsilon_{j k t}$. In all specifications, we include time fixed effects collected in the vector of year indicators $d_{t}$. Apart from the previously mentioned distance variable, we consider a parsimonious set of potential trade cost determinants $X_{j k t}$ : tariffs (defined as the log product of each partner's ratio of tariff revenue to imports), bilateral exchange rate volatility (measured as the standard deviation of the change in the logged nominal monthly exchange rate), gold standard adherence, membership in the British Empire, and the penetration of railroads (defined as the log product of each partner's ratio of railroad mileage to land area). Table 1 provides the summary statistics of our data, see the data appendix for the data sources. In Table 2 we report two separate regression specifications of equation (4). The first column presents our preferred results from a random effects specification. The second column presents the results from a country-pair fixed 
effects specification. Country-pair fixed effects control for unobservables or omitted factors at the country-pair level and therefore cannot separately estimate the impact of distance and membership in the British Empire. It can readily be seen that the inferences drawn from column 1 are highly robust to time-invariant heterogeneity at the country-pair level. We discuss the results from column 1.

Nations further apart - reassuringly - had higher trade costs. Taking 0.07 as the distance elasticity from column 1, the standardized coefficient for distance is measured as 0.40 . That is, a one standard deviation increase in the distance between countries would be associated with nearly a one half standard deviation increase in trade costs.

The sign of the log product of tariffs is consistent with reasonable priors, although we should note that we lack country-pair specific information on tariff barriers - that is, these measures capture the general level of protection afforded in French and US markets, for example, but not the protection afforded against French goods in US markets and vice versa. The point estimate suggests that a one percent rise in the log product of tariffs is associated with a two percent rise in trade costs.

Adherence to the gold standard also appears to be associated with lower trade costs. Adoption of the gold standard is predicted to bring about a roughly 3.6 percent decline in trade costs. As previous work has shown, credible exchange rate stability seems to go along with greater trade. Interestingly, exchange rate volatility itself does not seem to have any association with trade costs. A potential explanation lies in the fact that exchange rate volatility and the gold standard are strongly correlated: adherence to the gold standard entails virtually zero exchange rate volatility. This view is confirmed by regressions containing only exchange rate volatility; in this case, it is positively signed and significant.

When both countries are in the British Empire this is associated with 50 percent lower trade costs. This high number does not, however, suggest absurdly low trade costs between the UK and its colonies. It must be kept in mind that the British Empire was a far-flung affair, with distances from London in our sample ranging from a "mere" 5,376 kilometers for Canada to over 18,000 for Australia and New Zealand. Despite this moderating effect of distance, the privileges 
of imperial membership are hard to deny, a result which is consistent with the emerging view on empire and trade (Mitchener and Weidenmier, 2007).

The period we are considering is widely regarded to be one of improved infrastructure and declining shipping costs. In our regressions we find some support for the view that domestic transportation infrastructure matters for international trade costs. The standardized 'beta' coefficient on railroad density is -0.14 . In other words, a one standard deviation increase in the total length of a dyad's railway network (relative to land area) would have decreased trade costs by about one-seventh of a standard deviation.

To understand how each of the trade cost proxies used above affects actual trade levels, one would need further information on the elasticity of substitution. For instance, we find that the gold standard may have decreased trade costs by 3.6 percent. This finding is compatible with the seemingly larger effect of the gold standard on bilateral trade (roughly 30 percent or more in the literature) because what matters is the interaction between the elasticity of substitution and the estimated impact of the gold standard on trade costs (see equation (1)).

Overall we find that our trade cost measure relates sensibly to standard proxies for trade costs. Naturally this should be the case since what we have undertaken is only one small, but non-obvious, step beyond what standard gravity models of trade do when they use a vector of trade cost proxies in regressions explaining bilateral trade. Our regressions show that an overall decline of trade costs of 10 to 15 percent over the entire period can be reconciled with the following interpretation: trade costs are a function of many variables and over time some rose, some declined and others stayed roughly constant; rising tariffs partially offset declining freight rates; finally, other trade cost components related to factors that are more difficult to measure fell slightly but not massively. Being more precise about the particular factors that mattered at the bilateral level merits further study.

\section{Accounting for the Increases in Global Trade 1870-1913}

Finally, we return to our key question: what accounts for the marked increase in global trade flows between 1870 and 1913? The existing literature on the pre-World War I and post-World 
War II waves of globalization offers likely suspects. On the one hand, much of the historical literature has emphasized reductions in trade costs, specifically those arising from endogenous changes in commercial policy and exogenous changes in transport technology (O'Rourke and Williamson, 1999). On the other hand, much of the contemporary literature has emphasized secular patterns in income growth and convergence (Baier and Bergstrand, 2001). What we aim for in this section is to relate changes in bilateral trade flows to changes in productive capacity and changes in trade costs in an accounting sense. Our micro-founded gravity model provides a straightforward way of doing this. To arrive at a "decomposition" of the factors affecting the growth of trade we perform the following exercise. Assuming that $s_{j}$ and $s_{k}$ are constant, we take the natural logarithm and then the first difference of gravity equation (1) to obtain

$\Delta \ln \left(E X P_{j, k t} E X P_{k, j t}\right)=\Delta \ln \left(\left(G D P_{j t}-E X P_{j t}\right)\left(G D P_{k t}-E X P_{k t}\right)\right)+(2 \rho-2) \Delta \ln \left(1-\tau_{j, k t}\right)$.

Then divide everything by $\Delta \ln \left(E X P_{j, k t} E X P_{k, j t}\right)$ to get

$$
1=100 \%=\frac{\Delta \ln \left(\left(G D P_{j t}-E X P_{j t}\right)\left(G D P_{k t}-E X P_{k t}\right)\right)}{\Delta \ln \left(E X P_{j, k t} E X P_{k, j t}\right)}+(2 \rho-2) \frac{\Delta \ln \left(1-\tau_{j, k t}\right)}{\Delta \ln \left(E X P_{j, k t} E X P_{k, j t}\right)} .
$$

The first term on the right-hand side accounts for increases in bilateral trade due to economic growth. The second term accounts for increases in trade due to a decline in bilateral trade costs. It is readily seen from (6) that the contribution of the decline in trade costs is invariant to the value of the elasticity of substitution because the share going to the GDP terms is given by the data. This is true even if the elasticity changes over time.

In deriving (6) we have implicitly assumed that the parameters $s_{j}$ and $s_{k}$, which indicate the fraction of all goods that are tradable, remain constant over time. For the post-World War II period this proves to be a realistic assumption as the increase in the range of tradable goods has been offset by the increase in nontradable services (Novy, 2007). If the output of tradable goods in fact increased faster than the output of nontradable goods, this would make the decline in trade costs less important in explaining the growth of trade but it would not affect the contribution of economic expansion. In that sense, the numbers that we report in 
this section can be seen as an upper bound for the contribution of the decline in trade costs.

In Table 3 we report the growth in trade for our balanced sample between 1870 and 1913 and the respective contributions of economic expansion and the decline in trade costs in explaining this trade boom. We carry out this exercise for various subsamples of our data set. The first row presents results for the full sample. Here we see that about 56 percent of the expansion of trade can be accounted for by changes in trading partners' productive capacity, whereas declines in trade costs account for about 44 percent of the growth in trade. These results suggest a slightly larger role for trade costs than the findings of Baier and Bergstrand (2001) who argued that two-thirds of the growth in trade amongst OECD countries between 1958 and 1988 was explained by the growth of output. But our framework also allows such calculations for specific country pairs.

For trade between the more economically advanced and proximate countries in Europe, economic expansion contributes the lion share to the expansion of trade. The decline in trade costs is much more important for the markets outside of Europe and America. Declines in trade costs with partners in Asia and Oceania are responsible for 65 and 56 percent of the increase in trade, respectively.

This geographical difference is consistent with the idea that in core-periphery trade between 1870 and 1913 real freight rates fell more quickly. There was also an expansion of trading networks through pro-active marketing strategies in new markets, new shipping lines were established, and telegraph connections in the less industrialized world improved. These factors together expanded trade with the less developed world despite the rapidly rising tariffs of many trading partners documented in Williamson (2006). The results from the core are also consistent with the fact that the majority of their communications infrastructure was in place well before 1880 and that the tariff backlash in Europe increased trade costs.

The decline in trade costs has the most explanatory power for the growth in US trade and the least explanatory power for the growth in British trade (see Table 3). One reason for this heterogeneity is that prior to our sample period the UK had already become well integrated into the world economy and generally had managed to lower trade costs far below those of the US 
and France (see Figure 3). This was due to its early free trade stance, its colonial connections and the proximity of economic activity to the sea.

Thus, to some extent the US and France caught up with the UK in reaping the benefits from lower trade costs as they penetrated markets that were once the domain of Britain. In explaining this phenomenon, the economic history literature (see the industry specific essays in Aldcroft, 1968) has focused on productivity versus trade barriers broadly defined. Our results appear consistent with the idea that the US and France increased their international market shares more by lowering trade costs than by scoring productivity gains.

Given that falling trade costs can only explain about 44 percent of the pre-World War I trade boom, an overriding role for communication and transportation technologies in the first wave of globalization is muted. This is for two reasons. Increases in tariffs put downward pressure on the fraction of the growth in trade attributable to falling trade costs. But secular increases in income were also key in fuelling the growth of trade. Overall, we are suggesting a view in which the primary mover of increased trade volumes is the secular increase in income with ancillary contributions from policy and technology. Assumptions about the parameters do not affect this conclusion. Nevertheless, overall declines in trade costs are almost by definition the largest contributor to the increases in the ratio of trade to output over the period as per the consensus in the literature. Our contribution is to find a way of measuring how large these changes could have been.

We should emphasize again that we obtain these decomposition results by using a standard framework of trade in differentiated goods with trade costs that is widely used and accepted in the literature (see Anderson and van Wincoop, 2003 and 2004). In particular, a unit income elasticity is standard in the theoretical gravity literature. Evenett and Keller (2002) derive gravity models from several leading theories of international trade, all of which are characterized by unit income elasticities. ${ }^{7}$ Thus, even if we allow for differences in the underlying modeling

\footnotetext{
${ }^{7}$ Anderson and van Wincoop (2003) allow for non-unit income elasticities by assuming that the share $\phi$ of income spent on tradables equals $Y^{\alpha}$, despite the fact that they themselves argue "there is no clear theoretical foundation for specifying the fraction spent on tradables as $Y^{\alpha}$." More alarmingly for proponents of the idea that trade costs are the key driver of integration, Anderson and van Wincoop note that $\alpha$ is likely to be greater than zero, implying an income elasticity greater than one. To the extent that their argument is valid, an imposed unit income elasticity provides an upper bound for the impact of trade costs.
} 
strategy, or the value of parameters underlying our trade cost calculations, the fact remains that changes in income will always explain a majority of the growth in bilateral trade for this period. As in all of the standard gravity literature, an implicit assumption in our paper is of course that aggregate trade costs are exogenous to economic expansion and the growth of trade. In our view, the theoretical exploration of endogenous trade costs is a fruitful avenue for future research.

\section{Conclusions}

We have studied the evolution and determinants of trade costs between 1870 and 1913 . The theoretical foundation for these trade costs represents a new way of explaining international trade integration that is much easier to implement empirically than existing general equilibrium gravity models of international trade. We now relate 'multilateral' resistance terms to observable variables. This provides a convenient way to compute, not estimate, implied bilateral international trade costs.

The patterns we have found suggest that overall trade costs did not decline dramatically after 1870 since tariffs and non-tariff barriers rose. In the face of a shipping cost plunge, and the elimination of exchange rate uncertainty for many trading partners, trade costs seem to have fallen by roughly ten to twenty percent. Slightly over 50 percent of the variation in these trade costs appears to be explained by proximity, policies, infrastructure, and the British Empire. Our measure can easily be extended to provide a quantitative grasp of qualitative observations made by country specialists and historians. They can also obviously be used in empirical research in international economics where a measure of trade costs is needed.

Finally, economic expansion and the decline in trade costs appear to be almost equally responsible for increasing international trade between 1870 and 1913. The trade boom of the nineteenth century therefore does not seem to be all about policy nor all about shipping and communications. Economic growth and productivity advances were also important drivers of the first wave of globalization. 


\section{Appendix A \\ Technical Appendix}

This appendix reproduces the model developed by Novy (2007). It outlines how to derive gravity equation (1). Moreover, it demonstrates that trade cost expression (2) holds even when countries run trade deficits or surpluses.

\section{A.1 Optimizing Consumers}

Optimizing consumers and firms inhabit $J$ countries with $j=1,2, \ldots, J$ and $J \geq 2$. The range of all consumers and of all goods produced in the world is the continuum $[0,1]$. Country $j$ comprises the consumer range $\left[n_{j-1}, n_{j}\right]$ and country- $j$ monopolistic firms each produce one differentiated good on the same range, where $n_{0}=0$ and $n_{J}=1$. It is assumed that the exogenous fraction $s_{j}$ of goods is tradable so that $\left[n_{j-1}, n_{j-1}+s_{j}\left(n_{j}-n_{j-1}\right)\right]$ is the range of all tradable goods produced by country $j\left(0<s_{j} \leq 1\right)$. These can be purchased by all consumers in the world. The remaining range $\left[n_{j-1}+s_{j}\left(n_{j}-n_{j-1}\right), n_{j}\right]$ represents country $j$ 's nontradable goods. The latter are available for purchase to country- $j$ consumers only.

Exogenous bilateral iceberg trade costs $\tau_{j, k}$ are incurred when goods are shipped from country $j$ to country $k$ where

$$
\tau_{j, k} \begin{cases}\geq 0 & \text { for } j \neq k \\ =0 & \text { for } j=k\end{cases}
$$

with $\tau_{j, k}<1$. It is assumed that bilateral trade costs are symmetric $\left(\tau_{j, k}=\tau_{k, j}\right)$. The assumption of zero intranational trade costs is a normalization which can also be found in Baier and Bergstrand (2001).

All consumers within one country are identical. They like consumption and dislike work such that their utility can be described as

$$
U_{j}=\ln C_{j}+\eta \ln \left(1-L_{j}\right)
$$

where $C_{j}$ and $L_{j}$ denote per-capita consumption and labor input in country $j$. The parameter $\eta$ is assumed to be identical across countries. $C_{j}$ is a CES Dixit-Stiglitz composite consumption index defined as

$$
C_{j} \equiv\left[\sum_{k=1}^{J} \int_{n_{k-1}}^{n_{k-1}+s_{k}\left(n_{k}-n_{k-1}\right)}\left(c_{j i}\right)^{\frac{\rho-1}{\rho}} \mathrm{d} i+\int_{n_{j-1}+s_{j}\left(n_{j}-n_{j-1}\right)}^{n_{j}}\left(c_{j i}\right)^{\frac{\rho-1}{\rho}} \mathrm{d} i\right]^{\frac{\rho}{\rho-1}}
$$

where $c_{j i}$ denotes the per-capita consumption of good $i$ in country $j$. The country- $j$ consumption index $(8)$ is defined over all tradable goods produced in the world, which is the left term within the brackets of (8), plus all nontradable goods produced by country $j$, which are given by the right term within the brackets. The parameter $\rho>1$ is the elasticity of substitution and it is assumed to be identical across countries.

The consumption-based price index, defined as the minimum expenditure for one unit of $C_{j}$, can be derived from (8) as

$$
P_{j}=\left[\sum_{k=1}^{J} \int_{n_{k-1}}^{n_{k-1}+s_{k}\left(n_{k}-n_{k-1}\right)}\left(\xi_{j i}\right)^{1-\rho} \mathrm{d} i+\int_{n_{j-1}+s_{j}\left(n_{j}-n_{j-1}\right)}^{n_{j}}\left(\xi_{j i}\right)^{1-\rho} \mathrm{d} i\right]^{\frac{1}{1-\rho}}
$$

where $\xi_{j i}$ denotes the prices of the individual goods as follows

$$
\xi_{j i}=\left\{\begin{array}{cl}
\frac{1}{1-\tau_{k, j}} p_{k i}^{T} & \text { for } \quad n_{k-1} \leq i \leq n_{k-1}+s_{k}\left(n_{k}-n_{k-1}\right) \quad \forall j, k \\
p_{j i}^{N T} & \text { for } \quad n_{j-1}+s_{j}\left(n_{j}-n_{j-1}\right) \leq i \leq n_{j}
\end{array}\right.
$$


$p_{k i}^{T}$ denotes the f.o.b. (free on board) price of the tradable good produced by country- $k$ firm $i$ and $p_{k i}^{T} /\left(1-\tau_{k, j}\right)$ is the c.i.f. (cost, insurance, freight) price of the same good when traded with country $j . \quad p_{j i}^{N T}$ is the price of the nontradable good produced by country- $j$ firm $i$. All prices are denominated in one world currency.

The c.i.f. price is $1 /\left(1-\tau_{k, j}\right)$ times the f.o.b. price because when one unit of a tradable good produced by a country- $k$ firm is shipped to country $j$, only the fraction $\left(1-\tau_{k, j}\right)$ arrives at the destination. The tariff equivalent $\theta_{k, j}$ of iceberg trade costs can be expressed as

$$
\theta_{k, j}=\frac{1}{1-\tau_{k, j}}-1=\frac{\tau_{k, j}}{1-\tau_{k, j}}
$$

Maximizing consumption (8) subject to the minimum expenditure (9) yields the standard individual demand function

$$
c_{j i}=\left(\frac{\xi_{j i}}{P_{j}}\right)^{-\rho} C_{j}
$$

The per-capita budget constraint in country $j$ is given by

$$
P_{j} C_{j}=W_{j} L_{j}+\pi_{j}
$$

where $W_{j}$ is the nominal wage and $\pi_{j}$ denotes per-capita nominal profits made by country- $j$ firms, which are fully redistributed to country- $j$ consumers.

\section{A.2 Optimizing Firms}

There is monopolistic competition such that each firm is the single producer of one differentiated good and sets the profit-maximizing price. Not all firms within one country are symmetric since in country $j$ the fraction $s_{j}$ of firms produces tradable goods, whereas the fraction $\left(1-s_{j}\right)$ produces nontradable goods. Let $y_{j i}^{T}$ denote the output produced by country- $j$ tradable firm $i$ and $y_{j i}^{N T}$ the output produced by country- $j$ nontradable firm $i$. In addition, let $y_{j i, k}^{T}$ be the tradable output of firm $i$ produced for country $k$ so that

$$
y_{j i}^{T} \equiv \sum_{k=1}^{J} y_{j i, k}^{T}
$$

All firms face a linear production function that has constant returns to scale and that operates with labor as the only input

$$
\begin{aligned}
& y_{j i, k}^{T}=A_{j} L_{j i, k}^{T} \\
& y_{j i}^{N T}=A_{j} L_{j i}^{N T}
\end{aligned}
$$

where $A_{j}$ is an exogenous and country-specific technology level that is assumed to be the same across the tradable and nontradable sectors. $L_{j i, k}^{T}$ and $L_{j i}^{N T}$ denote the amount of labor used to produce $y_{j i, k}^{T}$ and $y_{j i}^{N T}$ with

$$
L_{j i}^{T} \equiv \sum_{k=1}^{J} L_{j i, k}^{T}
$$

Note that since all consumers within one country are identical, they each spread their labor over all domestic firms according to how much labor input each firm needs. Since labor is assumed to 
be internationally immobile, domestic consumers do not work for foreign firms. As in Obstfeld and Rogoff (1995), production does not exhibit increasing returns to scale. Since the number of firms in country $j$ is given by the range $\left[n_{j-1}, n_{j}\right]$, their profits are determined endogenously. This framework is therefore consistent with the approach taken by, for instance, Anderson (1979) and Anderson and van Wincoop (2003) who assume that each region is specialized in the production of only one good.

Using demand function (12) market clearing for the tradable good produced by country- $j$ firm $i$ requires

$$
\left(1-\tau_{j, k}\right) y_{j i, k}^{T}=\left(\frac{\frac{1}{1-\tau_{j, k}} p_{j i}^{T}}{P_{k}}\right)^{-\rho}\left(n_{k}-n_{k-1}\right) C_{k}
$$

The right-hand side of (18) represents the amount of the tradable good $i$ that the $\left(n_{k}-n_{k-1}\right)$ consumers in country $k$ demand. The left-hand side is the amount of the same good that arrives in country $k$ after being shipped there from country $j$. Accordingly, market clearing for a country- $j$ nontradable good requires

$$
y_{j i}^{N T}=\left(\frac{p_{j i}^{N T}}{P_{j}}\right)^{-\rho}\left(n_{j}-n_{j-1}\right) C_{j}
$$

The profit function for tradable firm $i$ in country $j$ is

$$
\pi_{j i}^{T}=\sum_{k=1}^{J}\left(p_{j i}^{T} y_{j i, k}^{T}-W_{j} L_{j i, k}^{T}\right)
$$

where $W_{j}$ is the nominal wage that is the same across tradable and nontradable firms because workers are assumed to be mobile within countries. Plugging the production function (15) and the market-clearing condition (18) into (20) and maximizing with respect to $p_{j i}^{T}$ yields the standard markup

$$
p_{j i}^{T}=\frac{\rho}{\rho-1} \frac{W_{j}}{A_{j}}
$$

For nontradable firms the same procedure leads to

$$
p_{j i}^{N T}=\frac{\rho}{\rho-1} \frac{W_{j}}{A_{j}}
$$

so that

$$
p_{j i}^{T}=p_{j i}^{N T} \equiv p_{j}
$$

Thus, all country- $j$ firms set the same price $p_{j}$, irrespective of whether they produce tradable or nontradable goods.

\section{A.3 Equilibrium of the Model}

Since within one country all firms producing tradable goods are symmetric and all firms producing nontradable goods are also symmetric, the index $i$ will be dropped in the following. Each country- $j$ consumer maximizes utility (7) subject to budget constraint (13), leading to the optimal labor supply condition

$$
\frac{\eta}{1-L_{j}}=\frac{W_{j}}{P_{j} C_{j}}
$$


In order to solve the model it is useful to define per-capita output, per-capita labor supply and per-capita profits as

$$
\begin{aligned}
y_{j} & \equiv s_{j} y_{j}^{T}+\left(1-s_{j}\right) y_{j}^{N T} \\
L_{j} & \equiv s_{j} L_{j}^{T}+\left(1-s_{j}\right) L_{j}^{N T} \\
\pi_{j} & \equiv s_{j} \pi_{j}^{T}+\left(1-s_{j}\right) \pi_{j}^{N T}
\end{aligned}
$$

where $y_{j}^{T}$ is the same as $y_{j i}^{T}$ in (14), $L_{j}^{T}$ is the same $L_{j i}^{T}$ as in (17) and $\pi_{j}^{T}$ is the same as $\pi_{j i}^{T}$ in (20). The remaining right-hand side variables are the corresponding variables for nontradable firm $i$. Using the production functions (15) and (16) as well as the price markups (21)-(23) it follows

$$
\pi_{j}=p_{j} y_{j}-W_{j} L_{j}
$$

Combined with budget constraint (13) and the optimal labor supply condition (24) this yields the optimal per-capita labor supply

$$
L_{j}=\frac{\rho-1}{\rho-1+\rho \eta}
$$

Express nominal wages across countries as

$$
\alpha_{1} W_{1}=\alpha_{2} W_{2}=\ldots=\alpha_{j} W_{j}=\ldots=\alpha_{J} W_{J}
$$

where the $\alpha$ 's are auxiliary parameters yet unknown. It follows from the price markups (21)-(23) that

$$
p_{k}=p_{k}^{T}=\frac{\rho}{\rho-1} \frac{W_{k}}{A_{k}}=\frac{\rho}{\rho-1} \frac{\alpha_{j}}{\alpha_{k}} \frac{W_{j}}{A_{k}}
$$

Use (28) in price index (9) to derive

$$
P_{j}=\omega_{j}^{\frac{1}{1-\rho}} \frac{\rho}{\rho-1} W_{j}
$$

where

$$
\omega_{j} \equiv\left(\sum_{k=1}^{J} s_{k}\left(n_{k}-n_{k-1}\right)\left(A_{k}\left(1-\tau_{k, j}\right) \frac{\alpha_{k}}{\alpha_{j}}\right)^{\rho-1}\right)+\left(1-s_{j}\right)\left(n_{j}-n_{j-1}\right) A_{j}^{\rho-1}
$$

An expression for the real wage follows directly as

$$
\frac{W_{j}}{P_{j}}=\frac{\rho-1}{\rho} \omega_{j}^{\frac{1}{\rho-1}}
$$

Using budget constraint (13) and the optimal labor supply condition (24), expressions for consumption and real profits follow as

$$
\begin{aligned}
& C_{j}=L_{j} \omega_{j}^{\frac{1}{\rho-1}} \\
& \frac{\pi_{j}}{P_{j}}=\frac{L_{j}}{\rho} \omega_{j}^{\frac{1}{\rho-1}}
\end{aligned}
$$

as well as

$$
C_{k}=C_{j}\left(\frac{\omega_{k}}{\omega_{j}}\right)^{\frac{1}{\rho-1}}
$$


To solve for the $\alpha$ 's in (29), start off with (25) and plug in the market-clearing conditions (18) and (19). Then replace the price variables and consumption using (21)-(23), (28), (30) and (33) to yield

(34)

$$
\begin{aligned}
\frac{y_{j}}{A_{j}}=C_{j} \omega_{j}^{\frac{-\rho}{\rho-1}} & \left\{\left(\sum_{k=1}^{J} s_{k}\left(n_{k}-n_{k-1}\right)\left(A_{k}\left(1-\tau_{k, j}\right)\right)^{\rho-1}\left(\frac{\omega_{j}}{\omega_{k}} \frac{s_{j}}{s_{k}}\left(\frac{A_{j}}{A_{k}} \frac{\left(1-\tau_{j, k}\right)}{\left(1-\tau_{k, j}\right)}\right)^{\rho-1}\right)\left(\frac{\alpha_{k}}{\alpha_{j}}\right)^{-\rho}\right)\right. \\
& \left.+\left(1-s_{j}\right)\left(n_{j}-n_{j-1}\right) A_{j}^{\rho-1}\right\}
\end{aligned}
$$

At the same time, from the production functions (15) and (16), definitions (25) and (26) and expression (31) it follows

$$
L_{j}=\frac{y_{j}}{A_{j}}=C_{j} \omega_{j}^{\frac{-1}{\rho-1}}
$$

It must therefore be the case that the curly brackets in (34) are equal to $\omega_{j}$ as defined in (29). Setting the curly brackets equal to $\omega_{j}$ and using (29) yields

$$
\frac{\alpha_{k}}{\alpha_{j}}=\left(\frac{\omega_{j}}{\omega_{k}} \frac{s_{j}}{s_{k}}\left(\frac{A_{j}}{A_{k}} \frac{\left(1-\tau_{j, k}\right)}{\left(1-\tau_{k, j}\right)}\right)^{\rho-1}\right)^{\frac{1}{2 \rho-1}}
$$

Finally, plug (35) back into (29) to obtain

$$
\begin{aligned}
\omega_{j}= & \left(\sum_{k=1}^{J} s_{k}\left(n_{k}-n_{k-1}\right)\left(A_{k}\left(1-\tau_{k, j}\right)\right)^{\rho-1}\left(\frac{\omega_{j}}{\omega_{k}} \frac{s_{j}}{s_{k}}\left(\frac{A_{j}}{A_{k}} \frac{\left(1-\tau_{j, k}\right)}{\left(1-\tau_{k, j}\right)}\right)^{\rho-1}\right)^{\frac{\rho-1}{2 \rho-1}}\right) \\
& +\left(1-s_{j}\right)\left(n_{j}-n_{j-1}\right) A_{j}^{\rho-1}
\end{aligned}
$$

The system of polynomial equations represented by (36) for $j=1,2, \ldots, J$ cannot be solved analytically. However, it can be established numerically by repeated substitution that a unique solution exists for the $\omega$ 's for all combinations of admissible parameter values. The admissible parameter values are $0<n_{k}-n_{k-1}<1,0<s_{k} \leq 1, \rho>1, A_{k}>0$ and $0 \leq \tau_{k, j}<1$ for all $j, k$. The implicit function theorem can be applied to compute the partial effects of changes in these exogenous parameters on the $\omega$ 's. The $\omega$ 's give rise to sensible general equilibrium effects for the real wage, consumption and real profits in (30)-(32). For example, a technology improvement in $A_{j}$ increases $\omega_{j}$ and therefore the real wage, consumption and real profits for country- $j$ citizens but, to a smaller extent, it also increases the other $\omega$ 's and is thus also beneficial to foreign citizens.

\section{A.4 A Gravity Equation with Trade Costs}

Given the equilibrium solution to the model, one can now derive the equilibrium trade flows between countries $j$ and $k$. Since all country- $j$ firms producing tradable goods are symmetric and since $s_{j}\left(n_{j}-n_{j-1}\right)$ is the overall number of these firms, all goods that leave country $j$ for destination country $k$ are given by

$$
E X P_{j, k}=s_{j}\left(n_{j}-n_{j-1}\right) y_{j, k}^{T}
$$

where $E X P_{j, k}$ denotes real exports from $j$ to $k$. Likewise, all goods that leave country $k$ for export to country $j$ are given by

$$
E X P_{k, j}=s_{k}\left(n_{k}-n_{k-1}\right) y_{k, j}^{T}
$$


As we are ultimately interested in bilateral trade costs and as these bilateral trade costs influence trade flows in both directions, we need to combine (37) and (38) in order to take all available information on trade flows into account. A useful way of combining unidirectional trade flows is to multiply them by each other. This yields

$$
E X P_{j, k} E X P_{k, j}=s_{j}\left(n_{j}-n_{j-1}\right) y_{j, k}^{T} s_{k}\left(n_{k}-n_{k-1}\right) y_{k, j}^{T}
$$

In order to derive gravity equation (1) plug the market-clearing condition (18) into the righthand side of (37) and use the country- $j$ versions of (28) and (35) and the country- $k$ versions of (30) and (31). Also use production function (15) and rearrange to yield

$$
\left(\frac{\omega_{j}}{\omega_{k}}\right)^{\frac{\rho-1}{2 \rho-1}}=\frac{\omega_{j} L_{j, k}^{T}\left(\frac{A_{j}}{A_{k}} \frac{\left(1-\tau_{j, k}\right)}{\left(1-\tau_{k, j}\right)}\right)^{\frac{\rho(\rho-1)}{2 \rho-1}}}{L_{k}\left(\frac{s_{k}}{s_{j}}\right)^{\frac{\rho}{2 \rho-1}}\left(n_{k}-n_{k-1}\right)\left(A_{j}\left(1-\tau_{j, k}\right)\right)^{\rho-1}}
$$

Plug the left-hand side of (40) into the right-hand side of (36), noting that $L_{j}=L_{k}$ from (27) and using (17) and (26). Also note that $L_{j, j}^{T}=L_{j}^{N T}$ as $p_{j}^{T}=p_{j}^{N T}$ by (23). Solve for $\omega_{j}$ to obtain

$$
\omega_{j}=\frac{\left(n_{j}-n_{j-1}\right) A_{j}^{\rho-1} L_{j}}{L_{j, j}^{T}}
$$

Plug the country- $j$ and country- $k$ versions of (41) back into the right-hand side of expression (37), where the right-hand side uses (18), (28), (30)-(31) and (35), and then rearrange to obtain

$$
\begin{aligned}
E X P_{j, k}= & \left(1-\tau_{j, k}\right)^{\frac{(\rho-1)^{2}}{2 \rho-1}}\left(1-\tau_{k, j}\right)^{\frac{\rho(\rho-1)}{2 \rho-1}}\left(s_{j}\right)^{\frac{\rho-1}{2 \rho-1}}\left(s_{k}\right)^{\frac{\rho}{2 \rho-1}} \times \\
& \left(\left(n_{j}-n_{j-1}\right) y_{j, j}^{T}\right)^{\frac{\rho}{2 \rho-1}}\left(\left(n_{k}-n_{k-1}\right) y_{k, k}^{T}\right)^{\frac{\rho-1}{2 \rho-1}}\left(\frac{n_{k}-n_{k-1}}{n_{j}-n_{j-1}}\right)^{\frac{1}{2 \rho-1}}
\end{aligned}
$$

Finally, note that $P O P_{j}=\left(n_{j}-n_{j-1}\right)$ and $P O P_{k}=\left(n_{k}-n_{k-1}\right)$, where $P O P_{j}$ is the population of country $j$. Also note from $(25)$ that $G D P_{j}=\left(n_{j}-n_{j-1}\right) y_{j}$ and

$$
\left(n_{j}-n_{j-1}\right) y_{j}=s_{j}\left(n_{j}-n_{j-1}\right) y_{j}^{T}+\left(1-s_{j}\right)\left(n_{j}-n_{j-1}\right) y_{j}^{N T}
$$

and by definition (14)

$$
s_{j}\left(n_{j}-n_{j-1}\right) y_{j, j}^{T}=s_{j}\left(n_{j}-n_{j-1}\right) y_{j}^{T}-s_{j}\left(n_{j}-n_{j-1}\right) \sum_{k \neq j} y_{j, k}^{T}
$$

Using $y_{j}^{N T}=y_{j, j}^{N T}=y_{j, j}^{T}$ as $p_{j}^{N T}=p_{j}^{T}$ it follows

$$
\left(n_{j}-n_{j-1}\right) y_{j, j}^{T}=\left(n_{j}-n_{j-1}\right) y_{j}-s_{j}\left(n_{j}-n_{j-1}\right) \sum_{k \neq j} y_{j, k}^{T}=G D P_{j}-E X P_{j}
$$

The same applies to $G D P_{k}-E X P_{k}$. Now plug $P O P_{j}, P O P_{k}, G D P_{j}-E X P_{j}$ and $G D P_{k}-E X P_{k}$ into (42) to obtain

$$
\begin{aligned}
E X P_{j, k}= & \left(1-\tau_{j, k}\right)^{\frac{(\rho-1)^{2}}{2 \rho-1}}\left(1-\tau_{k, j}\right)^{\frac{\rho(\rho-1)}{2 \rho-1}}\left(s_{j}\right)^{\frac{\rho-1}{2 \rho-1}}\left(s_{k}\right)^{\frac{\rho}{2 \rho-1}} \times \\
& \left(G D P_{j}-E X P_{j}\right)^{\frac{\rho}{2 \rho-1}}\left(G D P_{k}-E X P_{k}\right)^{\frac{\rho-1}{2 \rho-1}}\left(\frac{P O P_{k}}{P O P_{j}}\right)^{\frac{1}{2 \rho-1}}
\end{aligned}
$$


The corresponding gravity equation for $E X P_{k, j}$ follows analogously as

$$
\begin{aligned}
E X P_{k, j}= & \left(1-\tau_{k, j}\right)^{\frac{(\rho-1)^{2}}{2 \rho-1}}\left(1-\tau_{j, k}\right)^{\frac{\rho(\rho-1)}{2 \rho-1}}\left(s_{k}\right)^{\frac{\rho-1}{2 \rho-1}}\left(s_{j}\right)^{\frac{\rho}{2 \rho-1}} \times \\
& \left(G D P_{k}-E X P_{k}\right)^{\frac{\rho}{2 \rho-1}}\left(G D P_{j}-E X P_{j}\right)^{\frac{\rho-1}{2 \rho-1}}\left(\frac{P O P_{j}}{P O P_{k}}\right)^{\frac{1}{2 \rho-1}}
\end{aligned}
$$

As in (39), multiply (43) and (44) by each other and impose symmetry $\tau_{j, k}=\tau_{k, j}$ to obtain (1).

\section{A.5 Allowing for Trade Imbalances}

Most countries run trade deficits or surpluses. These trade imbalances often persist for some time until rebalancing is required. For example, Australia and Canada ran persistent current account deficits during our period of study. Novy (2007) incorporates trade imbalances into the model. The derivation is reproduced below. The conclusion is that trade imbalances wash out when the focus lies on symmetric trade costs such that trade cost measure (2) remains unaffected.

The model is therefore generalized to allow for trade imbalances. The per-capita budget constraint (13) is generalized to

$$
P_{j} C_{j}+\sum_{l=1}^{J} T_{j, l}=W_{j} L_{j}+\pi_{j}
$$

where $T_{j, l}$ are nominal per-capita transfers from country $j$ to $l$. As an accounting identity it follows

$$
\left(n_{j}-n_{j-1}\right) T_{j, l}=-\left(n_{l}-n_{l-1}\right) T_{l, j}
$$

For analytical convenience it is now assumed that per-capita transfers are a fraction of percapita consumption spending

$$
T_{j, l}=\mu_{j, l} P_{j} C_{j}
$$

with $\mu_{j, j}=0$ for all $j$ such that budget constraint (45) can be rewritten as

$$
\left(1+\sum_{l=1}^{J} \mu_{j, l}\right) P_{j} C_{j}=W_{j} L_{j}+\pi_{j}
$$

If $\sum_{l=1}^{J} \mu_{j, l}>0$, then $j$ is a creditor country and runs a net trade surplus.

The generalized model can now be solved as outlined above. The key equations are given in the following. The optimal labor supply condition (24) becomes

$$
\frac{\eta}{1-L_{j}}=\frac{W_{j}}{\left(1+\sum_{l=1}^{J} \mu_{j, l}\right) P_{j} C_{j}}
$$

The markups (21)-(23), per-capita output (27), the real wage (30) and real profits (32) are not affected. But if $j$ runs a surplus, this reduces per-capita consumption $C_{j}$

$$
C_{j}=L_{j} \omega_{j}^{\frac{1}{\rho-1}}\left(1+\sum_{l=1}^{J} \mu_{j, l}\right)^{-1}
$$

Intuitively, due to logarithmic utility in (7), output $L_{j}$ is constant. But if country $j$ transfers some of its output to other countries, then its domestic consumption must fall. 
Now use the notation

$$
\sum_{l=1}^{J} \mu_{j, l}=\frac{C A_{j}}{C O N S_{j}}
$$

where $C A_{j}$ denotes the nominal current account of country $j$ and $C O N S_{j}$ denotes its nominal consumption expenditure.

The equations corresponding to (43) and (44) are

$$
\begin{aligned}
E X P_{j, k}= & \left(1-\tau_{j, k}\right)^{\frac{(\rho-1)^{2}}{2 \rho-1}}\left(1-\tau_{k, j}\right)^{\frac{\rho(\rho-1)}{2 \rho-1}}\left(s_{j}\right)^{\frac{\rho-1}{2 \rho-1}}\left(s_{k}\right)^{\frac{\rho}{2 \rho-1}}\left(\frac{P O P_{k}}{P O P_{j}}\right)^{\frac{1}{2 \rho-1}} \times \\
& \left(G D P_{j}-E X P_{j}\right)^{\frac{\rho}{2 \rho-1}}\left(G D P_{k}-E X P_{k}\right)^{\frac{\rho-1}{2 \rho-1}}\left(\frac{1+\frac{C A_{j}}{C O N S_{j}}}{1+\frac{C A_{k}}{C O N S_{k}}}\right)^{\frac{\rho-1}{2 \rho-1}} \\
E X P_{k, j}= & \left(1-\tau_{k, j}\right)^{\frac{(\rho-1)^{2}}{2 \rho-1}}\left(1-\tau_{j, k}\right)^{\frac{\rho(\rho-1)}{2 \rho-1}}\left(s_{k}\right)^{\frac{\rho-1}{2 \rho-1}}\left(s_{j}\right)^{\frac{\rho}{2 \rho-1}\left(\frac{P O P_{j}}{P O P_{k}}\right)^{\frac{1}{2 \rho-1}} \times} \\
& \left(G D P_{k}-E X P_{k}\right)^{\frac{\rho}{2 \rho-1}}\left(G D P_{j}-E X P_{j}\right)^{\frac{\rho-1}{2 \rho-1}}\left(\frac{1+\frac{C A_{k}}{C O N S_{k}}}{1+\frac{C A_{j}}{C O N S_{j}}}\right)^{\frac{\rho-1}{2 \rho-1}}
\end{aligned}
$$

In the case of a balanced current account $\left(C A_{j}=C A_{k}=0\right)$ equations (49) and (50) simplify to (43) and (44). If $j$ becomes a surplus country $\left(C A_{j}>0\right)$, this implies an increase in trade flows $E X P_{j, k}$ from $j$ to $k$ and a decrease in trade flows $E X P_{k, j}$. Multiply (49) and (50) by each other and impose symmetry $\tau_{j, k}=\tau_{k, j}$ to obtain (1), which in turn implies (2). Trade cost measure (2) therefore also holds in the more general case when countries run trade deficits or surpluses. 


\section{Appendix B The Sensitivity of Trade Costs to Parameter Assumptions}

This appendix shows that our results are not highly sensitive to the assumed elasticity of substitution and the tradable share. As mentioned, the relative ordering of trade costs is stable with respect to perturbations in both the elasticities of substitution and the tradable shares. Our reported regression results, which estimate the elasticity of trade costs with respect to a change in the observable trade cost proxies, are strongly robust to reasonable shifts in the parameters.

The following two figures plot the evolution of the log change of trade costs for plausible ranges of the elasticity of substitution and tradable shares for the United States and the United Kingdom between 1870 and 1913.

We assume that the elasticity of substitution is 11 . But suppose in fact it is an unrealistically distant 5. For this particular series, the change between 1870 and 1913 is off by about onethird. In this case, our headline finding of a 15 percent fall in US trade costs would, in such a circumstance, have to be revised to yield a 20 percent fall. Such a revision would not alter our qualitative findings. The change in trade costs is negatively related to the elasticity of substitution.

There is, however, a large difference in the levels. The levels are doubled when moving from 11 down to 5 . If the elasticity of substitution is far from its assumed value, it would not be prudent to take the exact levels of trade costs at face value. Also we do not explore what happens when the elasticity moves over time. But as Broda and Weinstein (2006) suggest for the post-1970 period, this parameter is quite stable.

For unrealistically large perturbations in the tradable share of goods, $s$, the levels of trade costs are fairly stable. The figure below shows only slight variation in levels when $s$ moves from 0.6 to 0.8 . There is no change in the first differences of trade costs for different values of tradable shares as this parameter enters multiplicatively.

What happens if the tradable share changes over time? If the change is small, then not much is the answer. However, the assumption of a constant $s$ would tend to overstate any decline in trade costs in the case of a sizeable (but implausibly large) increase from 0.6 to 0.8. Conversely, any trade cost declines are understated when s actually falls.

So what is the most plausible path of the fraction of all goods produced that are tradable, $s$, in the nineteenth century case? It seems likely that $s$ stayed fairly constant. Tradability is not the same as whether a good is highly traded. It is also not simply the fraction of measured GDP devoted to trade. A nontradable good is inherently impossible to trade at any level of trade costs. A 'non-traded' good refers to the fact that little or no trade in a particular good will occur when trade costs are prohibitively high. If we see trade in a particular class of goods increasing over time in the nineteenth century, we believe that the vast majority is attributable to changes in trade costs rather than to a large increase in the fraction of goods that can be traded. For example, New Zealand did in fact export some dressed meat to Great Britain prior to refrigeration. However, this trade increased exponentially in the face of large reductions in their trade costs. Also, while there must have been some increase in the number of varieties produced that could be traded, it is equally the case that the period saw the advent of new economic activity that was inherently nontradable. Government provision of services and the service sector became increasingly more important in most of these economies. If $s$ fell somewhat, we may be understating the fall in trade costs but probably by not more than ten percent, as the second figure in this appendix illustrates.

Finally, consider the non-linearities involved. These create large increases in trade relative to GDP with seemingly small changes in trade costs. Take US-UK trade in 1900. A doubling of total trade between the two nations relative to the product of their GDP (minus exports) would have implied a decrease in trade costs by eight percent, all else being equal. Again, this percentage is not very sensitive to the elasticity of substitution. To cut iceberg trade costs from the actual 0.30 in 1900 to 0.10 , holding everything else constant, would have required both countries' export to GDP ratios to rise from roughly two percent to 25 percent. Such calculations also highlight that a doubling of the export to GDP ratio (a standard measure of integration) is compatible with much less than a halving of trade costs. 
Figure 1: Sensitivity of Trade Costs to Changes in Elasticity of Substitution, US-UK, 1870-1913

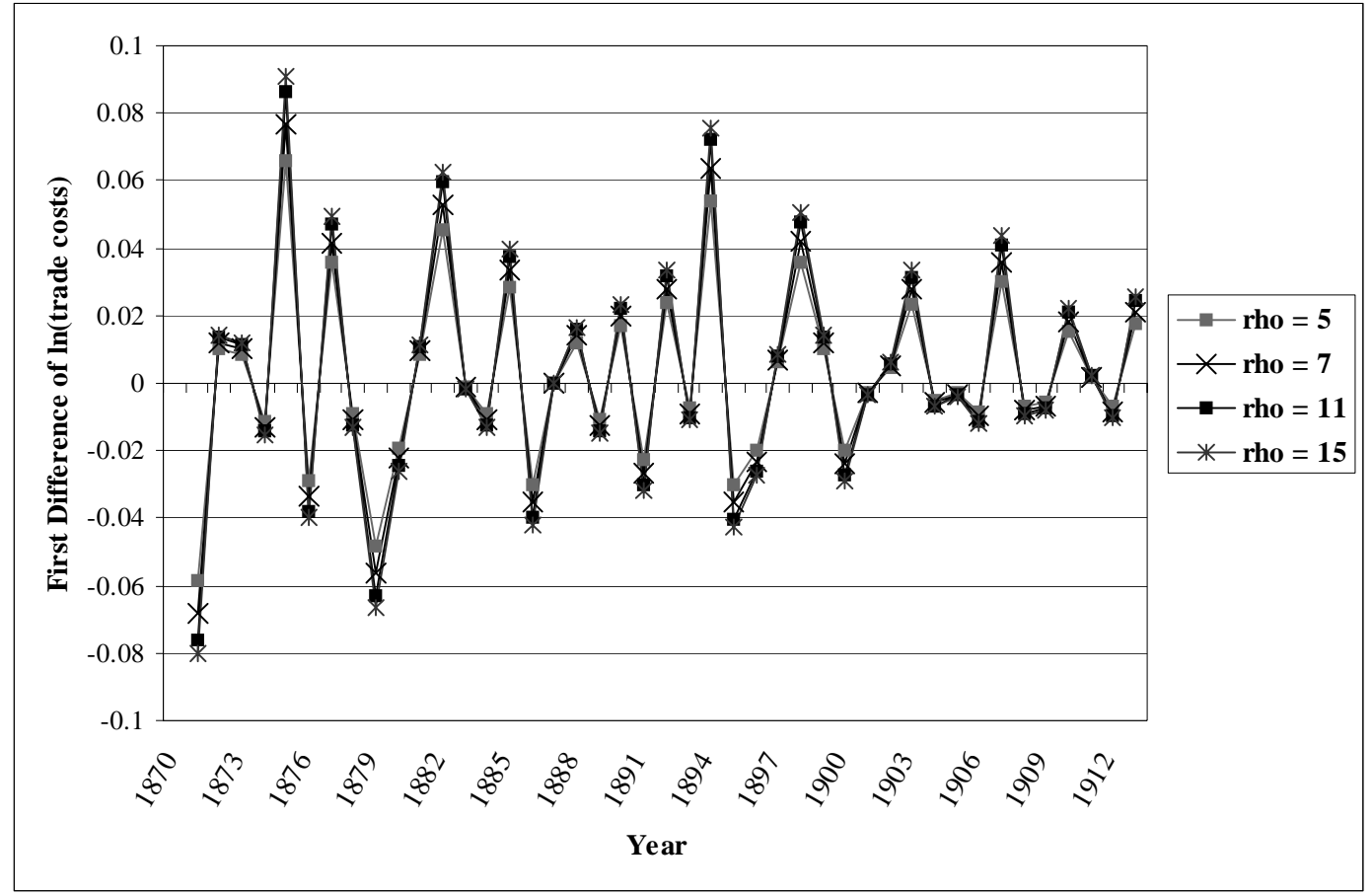

Figure 2: Sensitivity of Trade Costs to Tradable Share, US-UK, 1870-1913

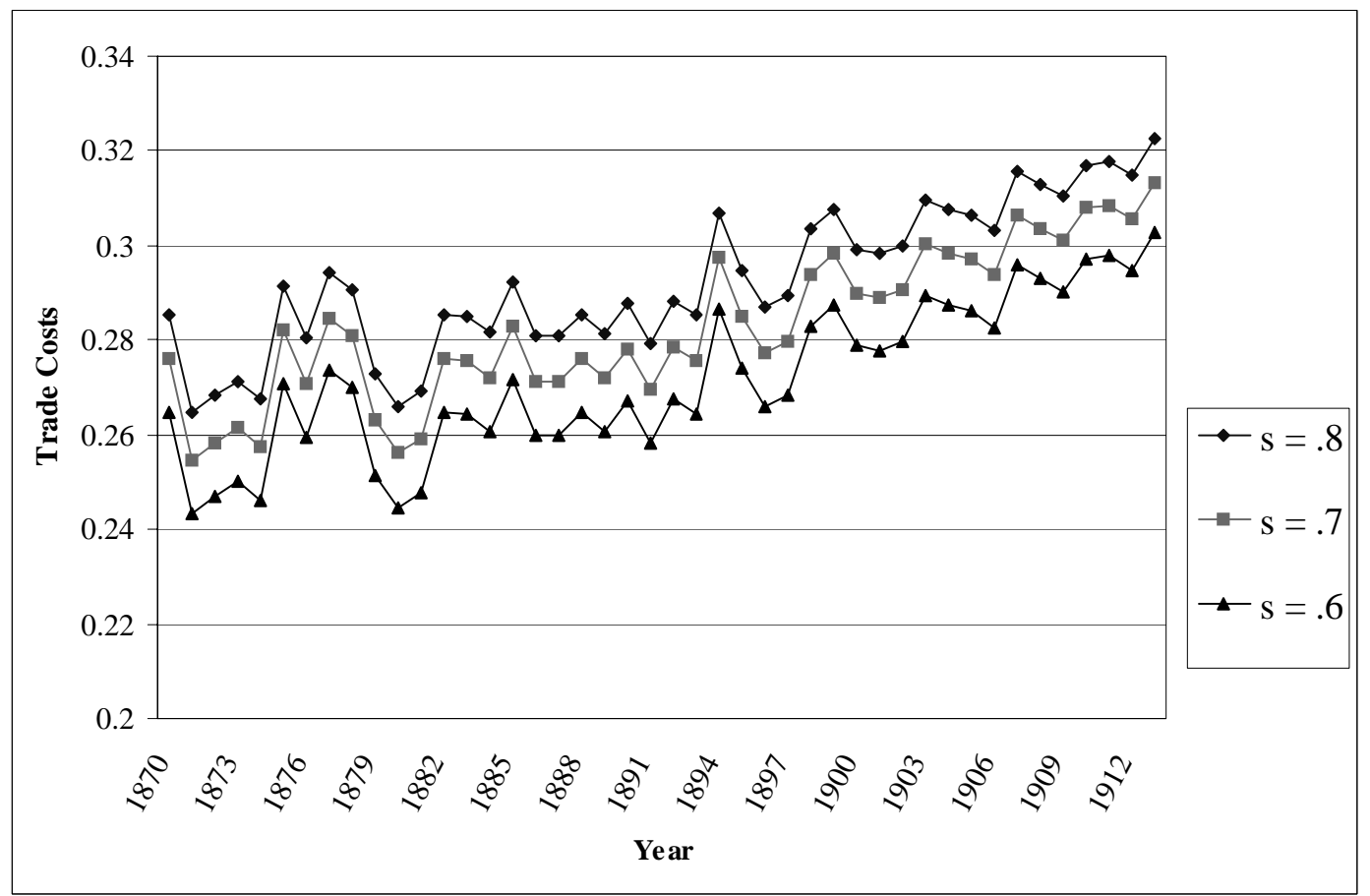




\section{Data Appendix}

Bilateral trade: Taken from the Statistical Abstract of the United Kingdom (various years), Statistical Abstract of the United States (various years), and Tableau Général du Commerce de la France avec ses Colonies et les Puissances Etrangères (various years). Trade was converted into real 1990 US dollars using the US CPI deflator in Officer and Williamson (2007).

GDP: Taken from Maddison (1995).

Population: Taken from Mitchell (2003a, 2003b, 2003c).

Tariffs: Measured as total customs revenue divided by imports taken from Mitchell (2003a, 2003b, 2003c). Many observations come from data kindly provided to us by Michael Clemens and Jeffrey Williamson and are based on Clemens and Williamson (2004). Belgium is from Degrève (1982). Switzerland is from Ritzmann-Blickenstorfer (1996).

Gold standard adherence: Based on data underlying Meissner (2005) and equals one when both countries adhere to the gold standard.

Exchange rate volatility: Defined as the standard deviation of the monthly difference of logged nominal exchange rates in a given year. Taken from the Global Financial Database.

Distance: Measured as kilometers between capital cities. Taken from indo.com

Railroads and land area: Taken from Mitchell (2003a, 2003b, 2003c).

British Empire: Based on authors' recollection and equals one if both countries were members of the British Empire. 


\section{References}

Aldcroft, Derek H., The development of British industry and foreign competition, 1875-1914: Studies in industrial enterprise, London: George Allen and Unwin, 1968.

Anderson, James E., "A Theoretical Foundation for the Gravity Equation," American Economic Review, 1979, 69 (1), 106-116.

- and Eric van Wincoop, "Gravity with Gravitas: A Solution to the Border Puzzle," American Economic Review, March 2003, 93 (1), 170-192.

- and - , "Trade Costs," Journal of Economic Literature, September 2004, 42, 691-751.

Baier, Scott L. and Jeffrey H. Bergstrand, "The Growth of World Trade: Tariffs, Transport Costs, and Income Similarity," Journal of International Economics, 2001, 53, $1-27$.

Board of Trade, Statistical Abstract for the United Kingdom, London: HMSO, various years.

Broda, Christian M. and David E. Weinstein, "Globalization and the Gains from Variety," Quarterly Journal of Economics, 2006, 121, 541-585.

Clemens, Michael and Jeffrey G. Williamson, "Wealth Bias in the First Global Capital Market Boom," Economic Journal, April 2004, 114, 304-337.

Degrève, Daniel, Le Commerce Extérieur de la Belgique, 1830-1913-1939, Présentation Critique des Données Statistiques 1982.

Direction générale des douanes, Tableau général du commerce de la France avec ses colonies et les puissances étrangères, Paris: Imprimerie Nationale, various years.

Eaton, Jonathan and Samuel Kortum, "Technology, Geography and Trade," Econometrica, 2002, 70 (5), 1741-1779.

Estevadeordal, Antoni, Brian Frantz, and Alan M. Taylor, "The Rise and Fall of World Trade, 1870-1939," Quarterly Journal of Economics, 2003, 118, 359-407.

Evenett, Simon J. and Wolfgang Keller, "On Theories Explaining the Success of the Gravity Equation," Journal of Political Economy, 2002, 110 (2), 281-316.

Federico, Giovanni and Karl Gunnar Persson, "Market Integration and Convergence in the World Wheat Market, 1800-2000," in Kevin H. O'Rourke Tim Hatton and Alan M. Taylor, eds., The New Comparative Economic History: Essays in Honor of Jeffrey G. Williamson, Cambridge, MA: MIT Press, 2007, pp. 87-114.

Flandreau, Marc and Mathilde Maurel, "Monetary Union, Trade Integration and Business Fluctuations in 19th Century Europe: Just Do It," Working Paper 3087, CEPR November 2001

Frieden, Jeffry A., Global Capitalism: Its Fall and Rise in the Twentieth Century, New York: W.W. Norton, 2006.

Harley, C. Knick, "Ocean Freight Rates and Productivity, 1740-1913," Journal of Economic History, 1988, 48, 851-876.

Irwin, Douglas A., "Explaining America's Surge in Manufactured Exports, 1880-1913," Review of Economics and Statistics, May 2003, 82 (2), 364-376.

Jacks, David S., "Intra- and International Commodity Market Integration in the Atlantic Economy, 1800-1913," Explorations in Economic History, 2005, 42.

- , "What Drove Nineteenth Century Commodity Market Integration?," Explorations in Economic History, 2006, 42 (3), 383-412.

James, Harold, The End of Globalization, Cambridge: Cambridge University Press, 2001.

Krugman, Paul, "Scale Economies, Product Differentiation and the Pattern of Trade," American Economic review, 1980, 70, 950-959.

López-Córdova, J. Ernesto and Christopher M. Meissner, "Exchange Rate Regimes and International Trade: Evidence from the Classical Gold Standard Era," American Economic Review, 2003, 93 (1), 344-353.

Maddison, Angus, Monitoring the World Economy 1820-1992, Paris: Development Centre, OECD, 1995.

Meissner, Christopher M., "A New World Order: Explaining the International Diffusion of the Gold Standard, 1870-1913," Journal of International Economics, 2005, 66 (2), 385-406.

Mitchell, Brian R., International Historical Statistics. Africa, Asia $8 \mathcal{F}$ Oceania 1750-1988, New York: Stockton Press, 2003a.

- , International Historical Statistics. Europe 1750-1988, New York: Stockton Press, 2003b.

- , International Historical Statistics. The Americas 1750-1988, New York: Stockton Press, 
2003c.

Mitchener, Kris J. and Marc Weidenmier, "Trade and Empire," 2007. Mimeo, Santa Clara University.

Novy, Dennis, "Is the Iceberg Melting Less Quickly? International Trade Costs After World War II," Mimeo. University of Warwick, 2007.

Obstfeld, Maurice and Alan M. Taylor, Global Capital Markets: Integration, Crisis and Growth, Cambridge: Cambridge University Press, 2004.

- and Kenneth Rogoff, "Exchange Rate Dynamics Redux," Journal of Political Economy, $1995,103,624-606$.

- and - "The Six Major Puzzles in International Macroeconomics: Is There a Common Cause?," in Ben S. Bernanke and Kenneth Rogoff, eds., NBER Macroeconomics Annual, Cambridge: MIT Press, 2000.

Officer, Lawrence H. and Samuel H. Williamson, Purchasing Power of Money in the United States from 1774 to 2006, 2007. Downloaded from http://MeasuringWorth.com.

O'Rourke, Kevin H. and Jeffrey G. Williamson, "Late Nineteenth-Century Anglo-American Factor-Price Convergence: Were Heckscher and Ohlin Right?," Journal of Economic History, December 1994, 54 (4), 892-916.

- and - , Globalization and History: The Evolution of a Nineteenth-Century Atlantic Economy, Cambridge, Massachusetts and London: The MIT Press, 1999.

- and Ronald Findlay, "Commodity Market Integration, 1500-2000," in Alan M. Taylor Michael D. Bordo and Jeffrey G. Williamson, eds., Globalization in Historical Perspective, Chicago: The University of Chicago Press, 2003, chapter 1, pp. 13-62.

Ritzmann-Blickenstorfer, H., Statistique Historique de la Suisse, Zurich: Chronos, 1996.

Samuelson, Paul, "The Transfer Problem and Transport Costs: Analysis of Effects of Trade Impediments," Economic Journal, 1954, 64, 264-289.

Saul, S.B., Studies in British Overseas Trade, 1870-1914, Liverpool: Liverpool University Press, 1967.

Sessional Papers, Trade of the British Empire and foreign competition: despatch from $M r$ Chamberlain to the Governors of the Colonies and the High Commissioner of Cyprus and the replies thereto, Vol. lx of Parliamentary Papers, HMSO, 1897.

Shah Mohammed, S. I. and Williamson, Jeffrey G., "Freight Rates and Productivity Gains in British Tramp Shipping, 1869-1950," Explorations in Economic History, 2004, 41, $172-203$

Stockman, Alan C. and Linda Tesar, "Tastes and Technology in a Two-Country Model of the Business Cycle: Explaining International Comovements," American Economic Review, 1995, 85 (1), 168-185.

United States Department of Commerce, Statistical abstract of the United States: The National Data Book, Washington: US Government Printing Office, various years.

Whalley, John and Xian Xin, "Regionalization, Changes in Home Bias, and the Growth of World Trade," Working Paper 13023, National Bureau of Economic Research April 2007.

Williamson, Jeffrey G., "Explaining World Tariffs, 1870-1913: Stolper-Samuelson, Strategic Tariffs, and State Revenues," in H. Lindgren R. Findlay, H. Henriksson and M. Lundhal, eds., Eli Heckscher, International Trade, and Economic History, Cambridge, MA: MIT Press, 2006, pp. 199-228. 
Table 1: Summary Statistics of Data

\begin{tabular}{lllrrrr}
\multicolumn{1}{c}{ Variable } & Description & $\underline{\text { Obs }}$ & $\underline{\text { Mean }}$ & $\underline{\underline{\text { Std. Dev. }}}$ & $\underline{\text { Min }}$ & $\underline{\text { Max }}$ \\
Trade costs & Log of bilateral trade costs & 2097 & -0.9449 & 0.2143 & -1.4697 & -0.4155 \\
Distance & Log of great-circle distance in kilometers & 2097 & 8.1150 & 1.2586 & 5.5835 & 9.8509 \\
Tariffs & Log of the product of tariff revenues over import values & 2097 & -4.6885 & 1.3046 & -8.5980 & -0.4391 \\
ER volatility & Standard deviation of the change in logged nominal exchange rates & 2097 & 0.0077 & 0.0118 & 0.0000 & 0.1226 \\
Gold standard & Gold standard indicator equal to one if both countries adhere & 2097 & 0.6018 & 0.4896 & 0.0000 & 1.0000 \\
British Empire & British Empire indicator equal to one if both countries are members & 2097 & 0.0615 & 0.2403 & 0.0000 & 1.0000 \\
Railroads & Log of the product of railroad length over area & 2097 & -7.1549 & 2.0385 & -14.6003 & -3.8911
\end{tabular}

Table 2: The Determinants of Trade Costs, 1870-1913

Column 1: Random effects

\begin{tabular}{c} 
Coefficient \\
\hline $\mathbf{0 . 0 6 7 6}$ \\
$\mathbf{0 . 0 2 1 5}$ \\
0.0851 \\
$\mathbf{- 0 . 0 3 6 5}$ \\
$\mathbf{- 0 . 5 0 0 6}$ \\
$\mathbf{- 0 . 0 1 4 3}$
\end{tabular}

2097

0.5354
Column 2: Country-pair fixed effects

\begin{tabular}{cc} 
Std Error & p-value \\
\hline $\mathbf{0 . 0 1 7 0}$ & $\mathbf{0 . 0 0}$ \\
$\mathbf{0 . 0 0 2 8}$ & $\mathbf{0 . 0 0}$ \\
0.1066 & 0.43 \\
$\mathbf{0 . 0 0 3 4}$ & $\mathbf{0 . 0 0}$ \\
$\mathbf{0 . 0 8 7 4}$ & $\mathbf{0 . 0 0}$ \\
$\mathbf{0 . 0 0 1 9}$ & $\mathbf{0 . 0 0}$
\end{tabular}

Coefficient

0.0219

0.0945

$-\mathbf{0 . 0 3 6 5}$

$\overline{-0144}$

2097

0.2126

R-squared:

Notes: Dependent variable in all regressions is the log of trade costs; time fixed effects not reported.

See Table 1 for variable descriptions.

Standard errors are robust to heteroscedasticity and clustered at the country-pair level. 
Table 3: Accounting for Changes in Trade by Region, 1870-1913

\begin{tabular}{|c|c|c|c|c|}
\hline & & $\begin{array}{l}\text { Growth of } \\
\text { international trade }\end{array}$ & $\begin{array}{l}\text { Contribution of } \\
\text { output growth }\end{array}$ & $\begin{array}{l}\text { Contribution of } \\
\text { trade cost decline }\end{array}$ \\
\hline \multirow[t]{9}{*}{$\overline{\text { Full sample }}$} & $\begin{array}{l}\text { with all countries } \\
\mathrm{N}=48\end{array}$ & $\begin{array}{c}392.10 \% \\
\mathbf{1 0 0}\end{array}$ & 55.7 & 44.3 \\
\hline & with the Americas & $296.10 \%$ & & \\
\hline & $\mathrm{N}=8$ & 100 & 79.5 & 20.5 \\
\hline & with Asia & $572.30 \%$ & & \\
\hline & $\mathrm{N}=6$ & 100 & 35.3 & 64.7 \\
\hline & with Europe & $342.10 \%$ & & \\
\hline & $\mathrm{N}=30$ & 100 & 58.1 & 41.9 \\
\hline & with Oceania & $545.00 \%$ & & \\
\hline & $\mathrm{N}=6$ & 100 & 44.3 & 55.7 \\
\hline \multirow[t]{10}{*}{ France } & with all countries & $350.10 \%$ & & \\
\hline & $\mathrm{N}=17$ & 100 & 57.3 & 42.7 \\
\hline & with the Americas & $255.30 \%$ & & \\
\hline & $\mathrm{N}=3$ & 100 & 80.4 & 19.6 \\
\hline & with Asia & $484.70 \%$ & & \\
\hline & $\mathrm{N}=2$ & 100 & 34.7 & 65.3 \\
\hline & with Europe & $275.00 \%$ & & \\
\hline & $\mathrm{N}=10$ & 100 & 60.6 & 39.4 \\
\hline & with Oceania & $732.60 \%$ & & \\
\hline & $\mathrm{N}=2$ & 100 & 28.8 & 71.2 \\
\hline \multirow[t]{10}{*}{$\overline{\mathrm{UK}}$} & with all countries & $277.30 \%$ & & \\
\hline & $\mathrm{N}=17$ & 100 & 64.1 & 35.9 \\
\hline & with the Americas & $244.80 \%$ & & \\
\hline & $\mathrm{N}=3$ & 100 & 87.7 & 12.3 \\
\hline & with Asia & $581.90 \%$ & & \\
\hline & $\mathrm{N}=2$ & 100 & 28.3 & 71.7 \\
\hline & with Europe & $211.40 \%$ & & \\
\hline & $\mathrm{N}=10$ & 100 & 63.8 & 36.2 \\
\hline & with Oceania & $351.60 \%$ & & \\
\hline & $\mathrm{N}=2$ & 100 & 66.4 & 33.6 \\
\hline \multirow[t]{10}{*}{$\overline{\text { US }}$} & with all countries & $520.80 \%$ & & \\
\hline & $\mathrm{N}=17$ & 100 & 50.9 & 49.1 \\
\hline & with the Americas & $434.30 \%$ & & \\
\hline & $\mathrm{N}=2$ & 100 & 65.7 & 34.3 \\
\hline & with Asia & $650.30 \%$ & & \\
\hline & $\mathrm{N}=2$ & 100 & 42.8 & 57.2 \\
\hline & with Europe & $507.50 \%$ & & \\
\hline & $\mathrm{N}=11$ & 100 & 52.1 & 47.9 \\
\hline & with Oceania & $550.90 \%$ & & \\
\hline & $\mathrm{N}=2$ & 100 & 37.8 & 62.2 \\
\hline
\end{tabular}

Notes: All values in percent

18 countries in total

11 in Europe (Belgium, Denmark, France, Germany, Italy, Netherlands, Norway, Portugal, Spain, Sweden, UK)

3 in America (Brazil, Canada, US)

2 in Asia (Dutch East Indies, Japan)

2 in Oceania (Australia, New Zealand)

Balanced sample of trade costs (US, UK, France with 17 partners $33^{2}$ h)

Total observations: $48=3 * 17-3$ (eliminating 3 double observations due to symmetry, e.g. US-UK=UK-US) 
Figure 3: Average Trade Costs, France, UK, US, 1870-1913

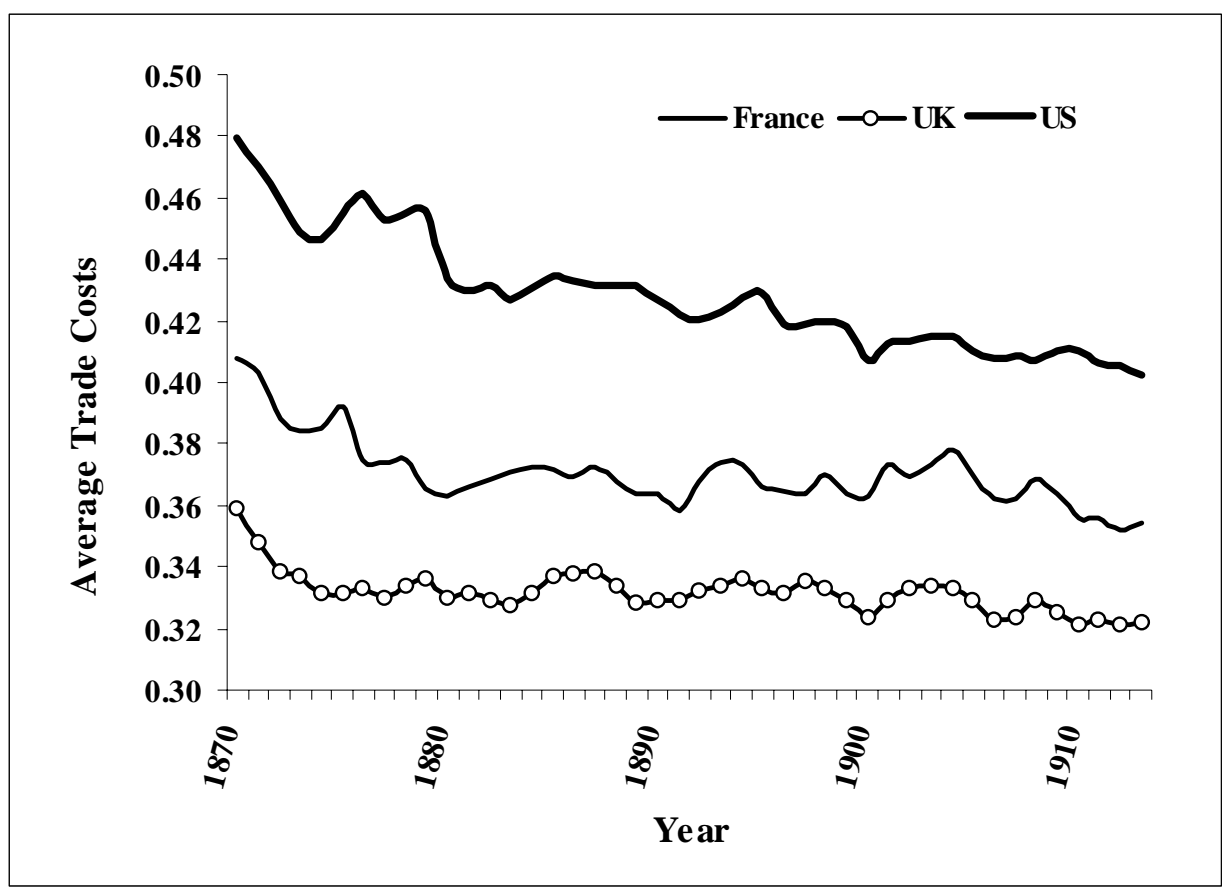

Figure 4: Index of Average Trade Costs, France, UK, US, 1870-1913

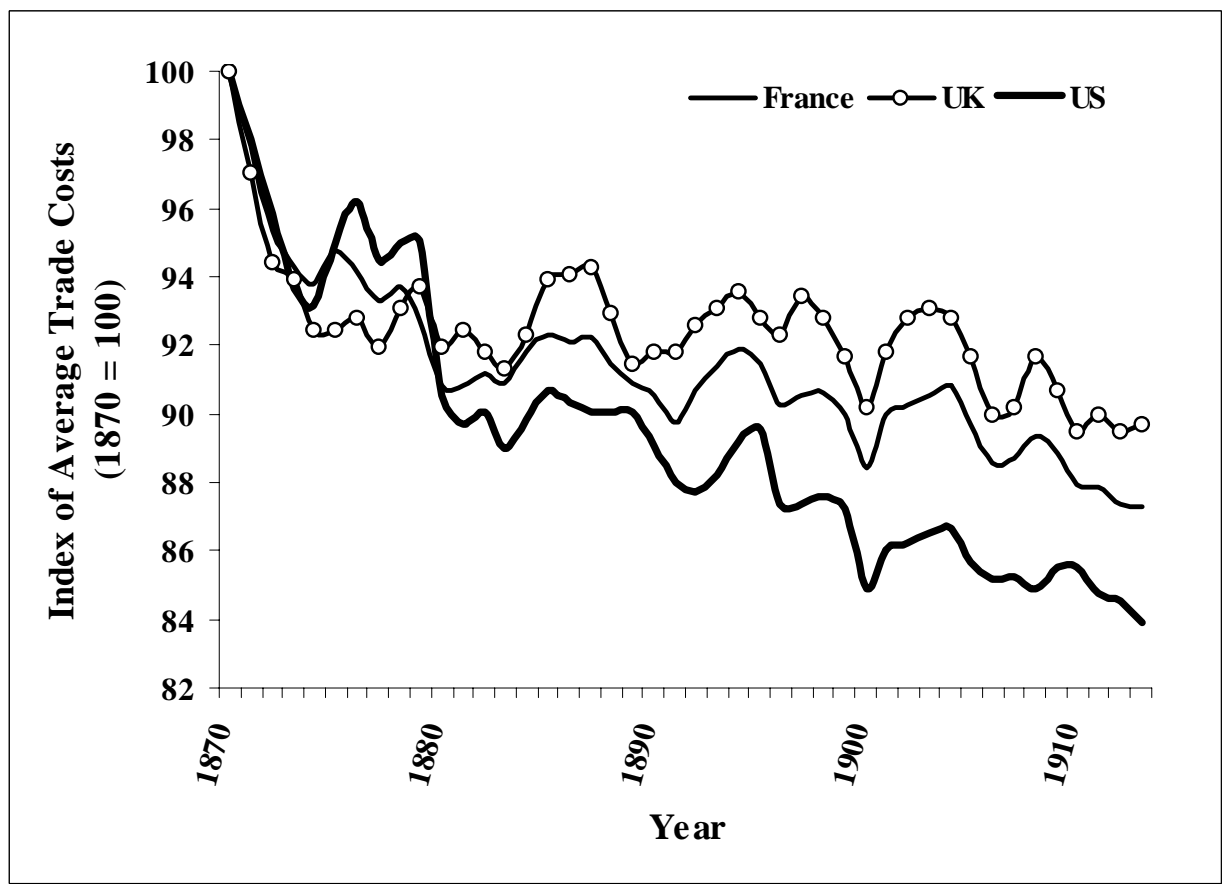

